〔ミニレビュー〕

\title{
サケ科魚類の致死性雑種と染色体異常
}

\author{
伊藤大一輔 $1 *$. 藤原篤志 ${ }^{2} \cdot$ 阿部周一 1 \\ 1 北海道大学大学院水産科学研究科、 2 (独) 水産総合研究センター養殖研究所、*現所属: 京都大学大学院生命科学研究科
}

\section{Hybrid Inviability and Chromosome Abnormality in Salmonid Fish}

\author{
Daisuke ITO $^{1}$, Atushi FUJIWARA ${ }^{2}$, Syuiti $\mathrm{ABE}^{1}$ \\ ${ }^{1}$ Graduate School of Fisheries Sciences, Hokkaido University \\ ${ }^{2}$ National Research Institute of Aquaculture \\ * Present address: Graduate School of Biostudies, Kyoto University
}

\section{1.はじめに}

魚類においては、雑種強勢を利用して成長率や肉質、 耐病性などの形質を向上させるために、異種間交雑種 が作出されてきた (Bartley ら 2000)。サケ科魚類は水 産上重要種を含むため、これまで育種を目的としてさ まざまな組み合わせの異種間交雑が試みられている (Chevassus 1979; Seeb ら 1988; McKay ら 1992; Gray ら 1993)。最近では、我国でもホウライニジマス早 $\times$ アマゴðもしくはイワナðの異質 3 倍体が「絹姫サー モン」としてブランド化され、東海地方を中心に刺身 用として出荷されている。しかし、異種間雑種の多く は生存率が低く不妊であることから、種間交雑により 有用品種が確立された例は少ないのが現状である(荒 井 1989；Gray ら 1993；Hulata 2001）。一部の致死性を 示す雑種においては、染色体の削減や断片化などの数 的・構造的異常が致死性の原因となることが示唆され ている(Arai 1984)。また、致死性を示すものの染色体 異常がみられない組み合わせもあり、雑種致死を引き 起こす機構は各々の両親種の組み合わせにより異なっ ていると考えられる。

本稿では、サケ科魚類の致死性雑種における染色体 異常について、我々の最新の研究成果をまじえて紹介 するほか、異種間雑種をいかにして水産育種に利用し てゆくべきかについて新たな視点で検討した。

\section{2. 致死性雑種における染色体異常}

サケ科魚類の雑種は組み合わせにより生存性を示す ものと、致死性を示すものがみられる(表1)。さらに、 生存性を示すものにも、妊性を示すものと不妊のもの がみられる。幾つかの致死性雑種においては染色体異 常が報告されており、致死性の原因のひとつと考えら
れている(表 2)。ここでは致死性雑種で生じる染色体 異常について詳しく調べられた例として、ニジマス $(2 \mathrm{n}=60)$ とサクラマス $(2 \mathrm{n}=66)$ の交雑について紹介 する。ニジマス早 $\times$ サクラマスð雑種胚は正常に発生 しふ化に至るが、雌雄逆のサクラマス早 $\times$ ニジマスの 雑種胚は発生異常を示し、ふ化に至らず死亡する (Suzuki と Fukuda 1971)。生存性雑種肧においては染 色体異常は全く認められないが、致死性雑種肧では染 色体数が両親種の半数和である 63 本よりも減少して おり、一部の細胞では染色体の断片化が観察されるこ とから、染色体削減と部分欠失の 2 種類の染色体異常 が起きることが示された。また、FISH (fluorescence in situ hybridization) 法の一種である染色体ペインティン グ法を用いて両親種由来の染色体を識別したところ、 これら 2 種類の染色体異常は全てオス親であるニジマ ス由来の染色体に特異的に起きていることが明らかに なった (Fujiwara ら 1997)。さらに、チミジンのアナロ グである BrdUを DNA 複製時に取り达ませることによ り、染色体に縞模様を生じさせる複製バンド法を用い て各染色体を同定した結果から、染色体削減は特定の ニジマス由来染色体に起きていることが示された (Fujiwara 1999)。このような染色体削減は、イワナ市 $(2 \mathrm{n}=84) \times$ シロザケð $(2 \mathrm{n}=74)$ (Arai 1984) やシロザ ケㅇニジマスð、カワマス $(2 \mathrm{n}=84) \times$ ニジマスる (Fujiwara 1999) など多数の異種間交雑で報告されてお

連絡先：阿部周一、北海道大学大学院 水産科学研究科

于 041-8611 北海道函館市港町 3-1-1

(e-mail: abesyu@fish.hokudai.ac.jp) 
表 1. サケ科雑種における親種の組み合わせおよび生存性 $(\bigcirc)$ と致死性 $(\times)$

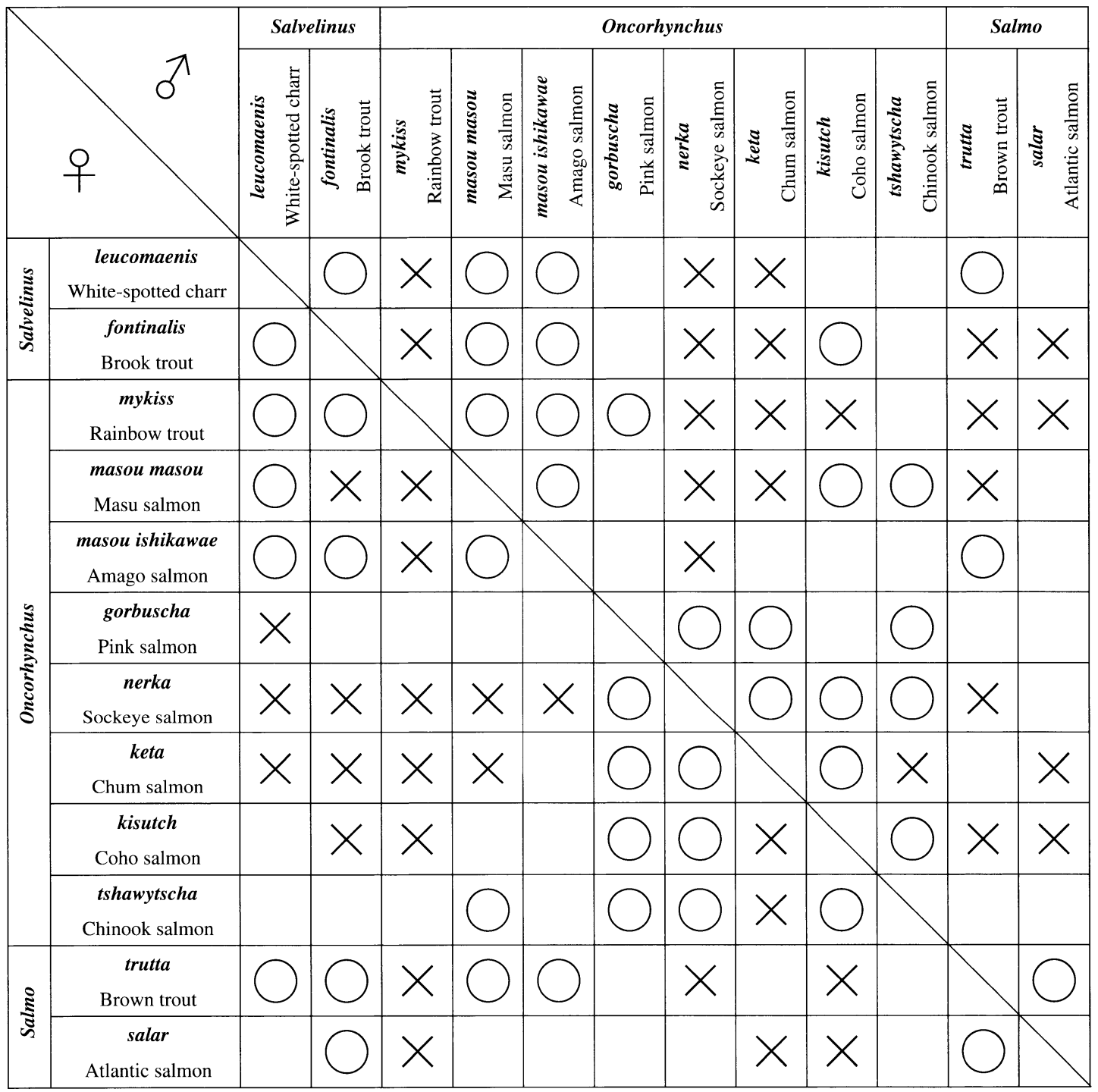

表 2. サケ科致死性雑種において認められた染色体異常

\begin{tabular}{|c|c|c|}
\hline Cross & Chromosome abnormalities & References \\
\hline 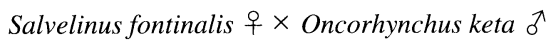 & Aneuploidy (hypodiploid) & Arai $(1984)$ \\
\hline S. fontinalis 우 $\times$ O. mykiss $\widehat{0}$ & $\begin{array}{l}\text { Aneuploidy (hypodiploid and hypotriploid) } \\
\text { Paternal chromosome elimination, partial deletion }\end{array}$ & Fujiwara (1999) \\
\hline S. leucomaenis 우 $\times$ O. keta $\widehat{\delta}$ & $\begin{array}{l}\text { Aneuploidy (hypodiploid) } \\
\text { Chromosome elimination }\end{array}$ & Arai (1984), Goodier et al. (1987) \\
\hline S. leucomaenis + $\times$ O. mykiss $\varnothing^{\nearrow}$ & Aneuploidy (hypodiploid and hypotriploid) & Ueda et al. (1990) \\
\hline O. keta 우 $\times$ O. mykiss $\widehat{0}$ & $\begin{array}{l}\text { Aneuploidy (hypodiploid) } \\
\text { Paternal chromosome elimination, partial deletion }\end{array}$ & Fujiwara (1999) \\
\hline O. masou 우 $\times$ O. mykiss $\widehat{\jmath}$ & $\begin{array}{l}\text { Aneuploidy (hypodiploid and hypotriploid) } \\
\text { Paternal chromosome elimination, partial deletion }\end{array}$ & Fujiwara et al. (1997) \\
\hline O. masou ishikawae 우 $\times$ O. mykiss $\widehat{\varnothing}$ & $\begin{array}{l}\text { Aneuploidy (hypodiploid) } \\
\text { Chromosome elimination }\end{array}$ & Kobayashi (1997) \\
\hline
\end{tabular}


り、致死性雑種における染色体異常の中で最も主要な ものの一つに挙げられる。

\section{3. イトウを用いた異種間交雑}

サケ科魚類の雑種を育種に用いるためには、さまざ まな交雑により、生じる雑種の特徴を調査する必要が あるが、サヶ科魚類の多くの種は秋から冬に産卵する ため、従来は春に産卵するイトウ Hucho perryi $(2 \mathrm{n}=62)$ を用いた異種間交雑は不可能であった。しかし、精子 の凍結保存技術の近年に扔ける向上（楠田 2004）によ り、産卵時期の異なる様々な種間で交雑を行うことが できるようになった。筆者らの研究グループではイト ウを用いた異種間交雑を試み、それぞれの雑種につい てその生存性、初期発生を調べ、致死性雑種について はその致死の原因を探るため、染色体異常の有無に着 目して研究を進めている。現在までに、いくつかの雑 種で過去に報告例のない染色体の数的掞よび構造的異 常が観察されて抢り、雑種致死の原因が予想以上に多 様であることがわかってきた。ここではその例として、 イトウとニジマスの正逆交雑と、シロザケ早 $\times$ イトウ ふの交雑について紹介する。

イトウとニジマスの正逆交雑に打いては、ニジマス + ×イトウす雑種胚は正常にふ化、浮上したものの、 雌雄逆のイトゥ早 $\times$ ニジマスぶ雑種胚は受精後 10 〜 20 日に急激に死亡しふ化に至るものはみられなかっ た。この致死性雑種肧では、エピボリーが進行してい るものの胚体がみられない奇形胚や矮小の肧体など、 様々な形態形成異常が観察された(図 1)。また、細胞 分裂像の観察からは、細胞分裂後期に分離が遅延する 染色体や分裂溝に残留する染色体が確認された(図 2)。 この致死性雑種胚は、染色体数により $\mathrm{A}$ (44～55 本)、 B (70 86 本)、C $(110 \sim 144$ 本) の 3 タイプに分類さ れた。さらに、これらの数的異常に加え染色体断片や 環状染色体などの構造的異常も観察された。染色体ぺ インティング法により両親種由来の染色体を識別した ところ、上記の A、B、Cタイプの胚は、イトウ由来 の染色体セット $(\mathrm{n}=31)$ をそれぞれ 1 組、2 組、4 組持 っていたが、いずれの場合もニジマス由来の染色体は 1 セット $(\mathrm{n}=30)$ より少ない 20 本以下しか持っていな かった。以上の結果から、イトウ早 $\times$ ニジマスふ雑種 肧ではイトウ由来の染色体セットが倍加したことに加 え、前述のサクラマス $\times$ ニジマスふ雑種肧と同様に、 ニジマス由来の一部の染色体が細胞分裂の過程で特異 的に脱落することが示された。異種間交雑により低三 倍体がみられた例は、イワナ早メニジマスる (Uedaら
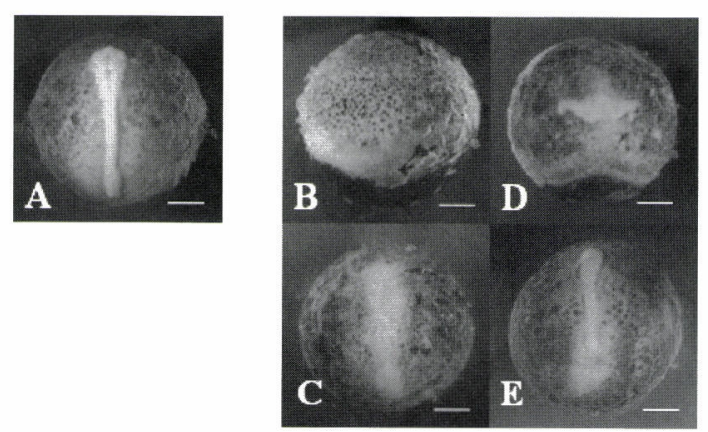

図1. 致死性イトウㅇ ×ニジマスふ雑種における受精 12 日目の肧形成。

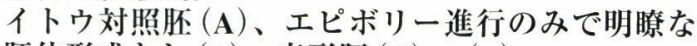
肧体形成なし $(\mathbf{B})$ 、奇形肧 $(\mathbf{C}) \sim(\mathbf{E})$ 。

スケールバー $1 \mathrm{~mm}$ 。
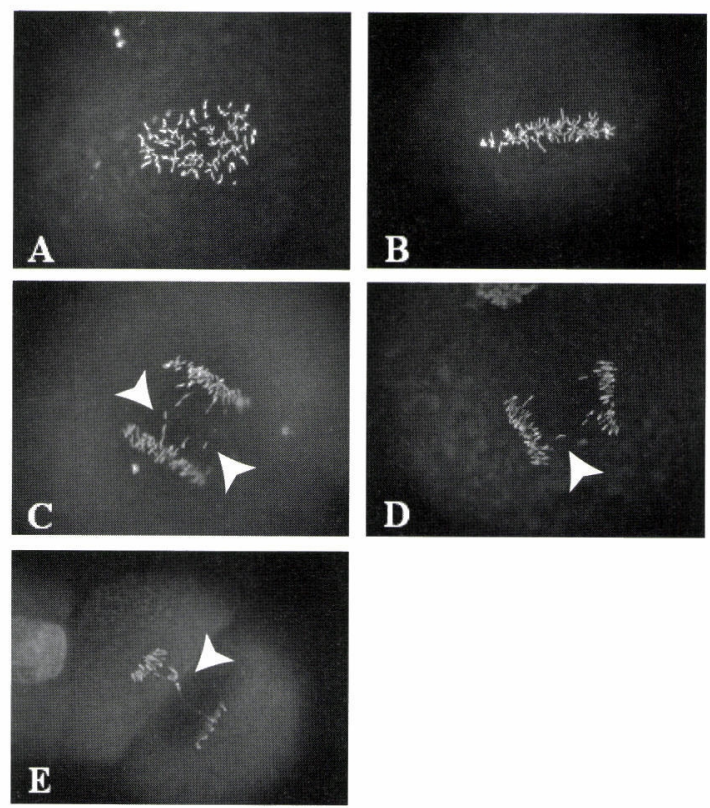

四 2. 致死性イトウ×ニジマスる雑種肧における DAPI 染色細胞分裂像。

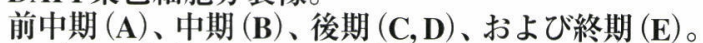
矢頭は分配遅延または紡錘体中央部に取り残され た染色体。

DAPI; 4',6-diamidino-2-phenylindole

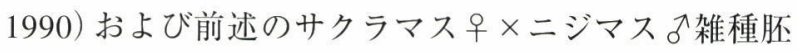
(Fujiwara ら 1997)に执いて報告されているが、メス由 来のゲノムが 4 倍まで増えた例は著者らの知る限り今 回のイトゥ早 $\times$ ニジスス雑種肧が初めてである。こ のゲノム倍加現象は、受精後の第二減数分裂と第一卵 割のどちらか、もしくは両方が阻害されて生じたと予 想されるが、その詳細は今後の遺伝学的解析から明ら かにしたい。 
一方、シロザケ早 メイトウす雑種肧は、イトウ早 $\times$ ニジマスふやサクラマス早 メジマスる雑種胚と同様 の致死性を示したが、その染色体構成はこれまでに報 告されている致死性雑種と大きく異なっていた。染色 体ペインティング法を用いた分析により、この雑種肧 には、シロザケ由来とイトウ由来の染色体セットをそ れぞれ 1 組ずつ持つ肧 (A タイプ) と、イトウ由来の染 色体が全くなくシロザケ由来の染色体のみで構成され る胚 (B夕イプ)の 2 タイプが、それぞれ約 $70 \%$ と $30 \%$ の頻度で観察された。このうち B タイプは雌性 発生により生じたと推察されるが、対照群のシロザケ $(2 \mathrm{n}=74)$ と異なり、染色体数は約 77 本 (最頻值) とい う異数性を示し、その中にはシロザケにはない大型の 異型染色体が見られるという奇妙な染色体構成を示し

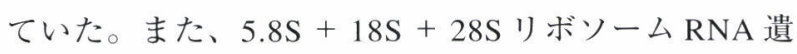
伝子をマーカーとするFISH 分析を行ったところ、蛍 光シグナルは、本来この遺伝子座を持つ染色体 (Alonso ら 1999) と形態的に異なる 3 本の染色体上に 検出された(図 3)。つまり、B夕イプに扔いては、リ ボソーム RNA 遺伝子座を卷き込んだ染色体の構造変 化が起きていることが明らかになった。このように、 シロザケ早メイトウす雑種胚においては、過去に例の ないほど複雑な染色体異常が起きていることが明らか になった。今回用いたイトウとシロザケのように、サ ケ科魚類の中でも系統分類学的に遠縁 (Oakley と Phillips 1999) とされる種間の交雑では、染色体の倍 加や再配列が起こりやすくなる傾向があるのかもし れない。

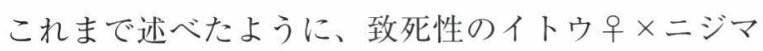
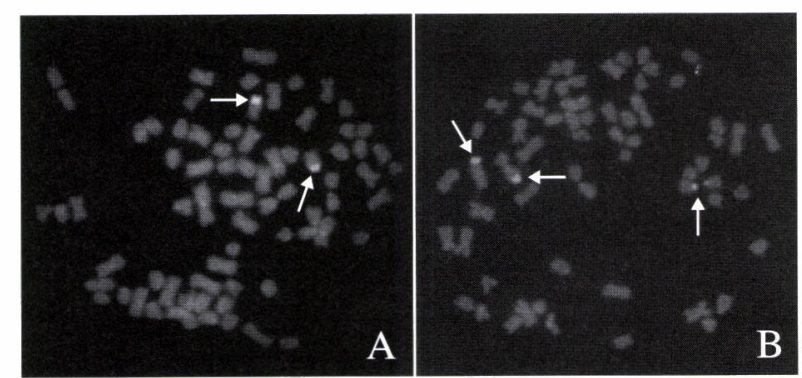

図 3. シロザケ対照 $(\mathbf{A})$ 扔よびシロザケ早 メイトウふの 交配により雌性発生した異数性肧（B）における $5.8 S+18 S+28 S$ リ゙ソーム RNA 遗伝子座 (矢印) の FISHによる分析。

本来一対 2 本の染色体末端に位置するこの遺伝子 座（A）は、雌性発生肧では全く別の3 本の染色 体上に認められた（B）。
スふおよびシロザケ゚×イトウす雑種肧では、オス由 来染色体の削減とメ又由来染色体の倍加、メ又由来染 色体の倍加と構造異常など、それぞれ異なる夕イプの 染色体異常がみられた。このことは、受精や体細胞分 裂にかかわる種特異的な因子の組み合わせが、染色体 の脱落や倍加といった個々の現象を方向づけているこ とを示唆しているのかもしれない。また、致死性雑種 では、尾芽肧期にあたる受精後 10〜20日に多くの胚 が死亡するが、このことは上述のさまざまな染色体異 常による遺伝的な摚乱が、尾芽肧期以降の発生を妨げ たためと考えられる。

\section{4. 染色体異常の発生メカニズム}

サケ科魚類の致死性種間雑種でみられる染色体異常 の成因については、まだよく分かっていない。サクラ マス早メニジマスふ雑種肧をはじめ、ニジマスをオス 親に用いた種々の種間雑種胚の組織学的観察によれ ば、細胞分裂中期から終期の染色体分配における一部 の染色体の移動遅延、姉妹染色分体の不分離、打よび 微小核形成が染色体削減の原因になっているのは確か らしい(Fujiwara ら 1997; Fujiwara 1999)。サクラマス 早 ×ニジマスす雑種胚におけるオス親由来の染色体が 特異的に削減される原因として、雄性発生二倍体や受 精直後の卵加圧处理による異質三倍体におけるオス由 来染色体の削減から、卵の細胞質と異種の精子ゲノム との不適合性 (incompatibility) によることが示唆され ている (Fujiwaraら 1997)。しかし、実際にどのような 細胞質因子が関わっているのか、目下のところ不明で ある。上述の姉妹染色分体の不分離から、染色体削減 を引き起こす原因として、紡錘体微小管と動原体との 接続エラーが可能性として挙げられる。動原体は、体 細胞分裂期に染色体の一次狭窄部であるセントロメア 領域に構筑されるタンパク質複合体であり、紡錘体微 小管との接続部位となる (Cleveland ら 2003)。両極か ら伸びた紡錘体微小管と動原体が接続することは、複 製された姉妹染色分体が正確に分配されるために重要 である。植物では、コムギとトウモロコシの雑種肧に おいて、トウモロコシ由来の染色体が細胞分裂の過程 で特異的に削減されるが、赤道面に残留したトウモロ コシ由来染色体の動原体は紡錘体微小管に接続してい ないことが観察された (Mochida ら 2004)。一方、サク ラマス早ニジマスす (Fujiwaraら 1997) 拈よびイト ウ $\times$ ニジマス雑種肧では、染色体は細胞分裂中期で赤 道面に整列していることが観察されたため、動原体と 紡錘体微小管との接続は正常であることが示唆され 
た。それにもかかわらず、サケ科致死雑種においては なぜ染色体が削減されるのであろうか? 一つの可能性 としては、動原体と紡鍾体微小管との接続は正常であ るものの、両極に姉妹染色分体を分配する動原体の機 能不全が考えられる。もしくは、細胞分裂中期から後 期に移行する際に、姉妹染色分体を接着させているコ ヒーシン複合体を分解し、姉妹染色分体を解離させる セパレースなどのタンパク質分解酵素の機能不全が考 えられる。最近、サケ科雑種と同様に致死性を示し、 オス親由来の染色体が細胞分裂の過程で削減されるメ ダカ雑種において、それぞれ異種由来の $\mathrm{Cdc} 2$ と Cyclin B からなる雑種型 MPF が異常な細胞分裂を引き 起こす可能性が示唆されている(岩井ら 2006)。今後 はサケ科雑種においても、このような可能性を検討し ていく必要があるだろう。

一方、卵の細胞質因子と不適合を起こすと予想され る精子ゲノムの因子については、どのように考えられ ているのだろうか。サクラマス早×ニジマスる雑種肧 においては、ニジマス由来の染色体はランダムではな く、一部の染色体が選択的に失われる傾向にあること が報告されている (Fujiwara 1999)。この例では、個々 のニジマス由来染色体の削減される頻度は、0\%(脱 落しない)〜 $100 \%$ (必ず脱落する)まで、ほぼ連続し た值をとることが示された。この結果は、削減の対象 となる染色体上に、それ自身の削減されやすさを決定 する量的なシス因子が存在することを示唆している。 また、交雑するメス親の種類によって異なるが、ニジ マス由来染色体は最大で半数程度まで削除されること から、このシス因子は殆どの染色体上に存在するもの と推察できる。このような条件に合うシス因子の候補 の一つとしては、動原体領域で高頻度に反復している 動原体 DNA が考えられる。一般に動原体 DNA は、 個々の染色体で反復回数が異なることが知られてお り、その量は染色体の細胞分裂時の安定性に影響する ことが知られている (Murphy と Karpen 1995; Vos 1998）。さらに、動原体DNA は前述した姉妹染色分体 の接着においても重要な役割を果たしていることが知 られている (Strunnikov 1998)。魚類の動原体DNAに ついての知見は未だに非常にそしいが、今後は、動原 体領域の構造ならびに機能解析も視野に入れて、染色 体削減の原因を追求していく必要があるだろう。

\section{5. 最後に}

致死性雑種は水産育種の観点から見ると直接の利用 は不可能なようであるが、雌性発生の誘起の成功率を
高めるために利用することが可能である。雌性発生法 は紫外線処理により不活性化した精子を用いて受精を 行い、続いて圧力処理や低温・高温処理により第二極 体の放出や第一卵割を阻害することによりメスのゲノ ムを倍加させる染色体セット操作の一種であり、クロ ーン系統や全雌集団を作出することができる（Arai 2001)。これまでの報告 (Suzuki と Fukuda 1971; Scheerer と Thorgaard 1983; Kobayashi 1997; Fujiwara ら 1997）と我々の実験結果より、ニジマスをオス親にし た場合生じる雑種はすべて致死性であることから、不 活性化したニジマスの精子を用いて雌性発生を誘起す れば、不活性化が不十分な精子により受精した肧は初 期発生過程で死亡するため、最終的には雌性発生胚の みが残ることになる。雑種が致死性となるような種の 精子を用いて、凍結保存技術と組み合わせることによ り人為雌性発生の効率を高めることに寄与できるもの と考える。

これまで、サケ科異種間雑種は水産育種上の利用を 目指して研究が進められてきたが、今後は育種目的の みならず、受精や体細胞分裂、形態形成など初期胚発 生の基本的な機構を理解するモデルとして有用となり 得るであろう。雑種に特有のさまざまな生物学的現象 を解明するためには、更に遗伝学的、生化学的な分析 を行うための基礎を確立することが急務である。

\section{参考文献}

Alonso M, Fujiwara A, Yamaha E, Kimura S, Abe S. 1999. Ribosomal RNA gene loci and silver-stained nucleolar organizer regions associated with heterochromatin in Alaskan char Salvelinus malma and chum salmon Oncorhynchus keta. Hereditas, 131: 221-225.

Arai K. 1984. Developmental genetic studies on salmonids: morphogenesis, isozyme phenotypes and chromosome in hybrid embryos. Memoirs of Fisheries Sciences, Hokkaido University, 31: 1-91.

荒井克俊. 1989. 水産増養殖と染色体操作. “異質倍 数体の項執筆”. 鈴木亮編. 日本水産学会監修. 82-94. 恒星社厚生閣. 東京.

Arai K. 2001. Genetic improvement of aquaculture finfish species by chromosome manipulation techniques in Japan. Aquaculture, 197: 205-228.

Bartley DM, Rana K, Immink AJ. 2000. The use of interspecific hybrids in aquaculture and fisheries. Reviews in Fish Biology and Fisheries, 10: 325-337.

Chevassus B. 1979. Hybridization in salmonids: results 
and perspectives. Aquaculture, 17: 113-128.

Cleveland DW, Mao YH, Sullivan KF. 2003. Centromeres and kinetochores: From epigenetics to mitotic checkpoint signaling. Cell, 112: 407-421.

Fujiwara A, Abe S, Yamaha E, Yamazaki F, Yoshida MC. 1997. Uniparental chromosome elimination in the early embryogenesis of the inviable salmonid hybrids between masu salmon female and rainbow trout male. Chromosoma, 106: 44-52.

Fujiwara A. 1999. Molecular cytogenetic studies on the hybrid inviability in salmonid fishes. Ph.D. Thesis, Hokkaido University, Sapporo, Japan.

Goodier J, Ma HF, Yamazaki F. 1987. Chromosome fragmentation and loss in two salmonid hybrids. Bulletin of Fisheries Sciences, Hokkaido University, 38: $181-184$.

Gray AK, Evans MA, Thorgaard GH. 1993. Viability and development of diploid and triploid salmonid hybrids. Aquaculture, 112: 125-142.

Hulata G. 2001. Genetic manipulations in aquaculture: a review of stock improvement by classical and modern technologies. Genetica, 111: 155-173.

岩井俊治、横田雄洋、酒井千春、金野芙美子、山下正 兼. 2006. メダカ雑種の特殊な生殖と発生から学 ぶ細胞分裂と生殖細胞形成の分子細胞機構. 水産 育種 35、印刷中.

Kobayashi T. 1997. Survival and cytological observations on early development of normal, hybrid, and gynogenetic embryos of amago salmon. Fisheries Science, 63: 33-36.

楠田聡. 2004. 魚類精子と肧細胞の凍結保存における 現状と展望. 水産育種, 34: 1-25.

McKay LR, Ihssen PE, McMillan I. 1992. Early mortality of tiger trout (Salvelinus fontinalis $\times$ Salmo trutta) and the effects of triploidy. Aquaculture, 102: 43-54.

Mochida K, Tsujimoto H, Sasakuma T. 2004. Confocal analysis of chromosome behavior in wheat $\times$ maize zygotes. Genome, 47: 199-205.

Murphy TD, Karpen GH. 1995. Localization of Centromere Function in a Drosophila minichromosome. Cell, 82: $599-609$.

Oakley TH, Phillips RB. 1999. Phylogeny of salmonine fishes based on growth hormone introns: Atlantic (Salmo) and Pacific (Oncorhynchus) salmon are not sister taxa. Molecular Phylogenetics and Evolution,
11: $381-393$

Seeb JE, Thorgaard GH, Utter FM. 1988. Survival and allozyme expression in diploid and triploid hybrids between chum, chinook, and coho salmon. Aquaculture, 72: 31-48.

Scheerer PD, Thorgaard GH. 1983. Increased survival in salmonid hybrids by induced triploidy. Canadian Journal of Fisheries and Aquatic Science, 40: $2040-2044$.

Strunnikov AV. 1998. SMC proteins and chromosome structure. Trends in Cell Biology, 8: 454-459.

Suzuki R, Fukuda Y. 1971. Survival potential of F1 hybrids among salmonid fishes. Bulletin of Freshwater Fisheries Research Laboratory, 21: 69-83.

Ueda T, Ojima Y, Kobayashi J. 1990. Hypodiploid and hypotriploid hybrids between female Japanese char and male rainbow trout. La Kromosomo, 59-60: $2008-2012$.

Vos JMH. 1998. Mammalian artificial chromosomes as tools for gene therapy. Current Opinion in Genetics and Development, 8: 351-359. 